\title{
GPRC5D wt Allele
}

National Cancer Institute

\section{Source}

National Cancer Institute. GPRC5D wt Allele. NCI Thesaurus. Code C147935.

Human GPRC5D wild-type allele is located in the vicinity of 12p13.1 and is approximately $39 \mathrm{~kb}$ in leng th. This allele, which encodes G-protein coupled receptor family C group 5 member $\mathrm{D}$, is involved in $\mathrm{G}$ protein-coupled receptor signaling. 